\title{
38. GEOCHEMISTRY, CARBON AND OXYGEN STABLE ISOTOPE COMPOSITION, AND DIAGENETIC TEXTURAL FEATURES OF LOWER CRETACEOUS PELAGIC CYCLIC SEDIMENTS FROM THE WESTERN NORTH ATLANTIC, DEEP SEA DRILLING PROJECT HOLE 603B ${ }^{1}$
}

\author{
Miriam Baltuck, Department of Geology, Tulane University²
}

\begin{abstract}
Compositional, textural, and oxygen and carbon stable isotopic analysis of Lower Cretaceous pelagic cyclic sediment is necessary in order to understand the mechanisms causing isotopic fluctuation. Pelagic cycles consist of dark, laminated marl, containing $75-80 \% \mathrm{CaCO}_{3}$ and typically about $0.5 \%$ organic carbon, alternating with lighter, bioturbated limestone (about $90 \% \mathrm{CaCO}_{3}$ and $0.1 \%$ organic carbon). The dark marl consistently contains heavier $\delta^{18} \mathrm{O}$ and $\delta^{13} \mathrm{C}$ than the light limestone. Scannning electron microscope observations indicate significant dissolution and diagenetic precipitation of carbonate in the limestone but only minor precipitation of carbonate in the dark marl. This suggests that lighter oxygen in the limestone has its origin in diagenetic precipitation at elevated burial temperatures. The shift toward heavier carbon in the marl end member may have more basis in changing paleoceanographic conditions.
\end{abstract}

\section{INTRODUCTION}

Laminated and cyclic sediments are widespread in the Lower Cretaceous of the North Atlantic (Fig. 1). Estimates of the duration of a Lower Cretaceous pelagic cycle at different sites on land and on the seafloor range over several tens of thousands of years. Best-constrained estimates cluster around 50,000 yr. (e.g., Dean et al., 1978; Arthur and Fisher, 1977; Robertson and Bliefnick, 1983 ) and 40,000 yr. (e.g., Arthur and Natland 1979, and Site 603 chapter, this volume). Generally the lightdark alternating sediments are of pelagic origin, but many sites illustrated in Figure 1 commonly contain sediments indicating an influx of terrigenous clastics or redeposited pelagics.

This is true of the Lower Cretaceous section of Site 603 drilled during Leg 93 . The transported material is composed of redeposited pelagic material, and in describing and selecting samples care must be taken not to confuse a turbidite composed of pelagic constituents and exhibiting a light (coarse basal layers) to dark (finer tops of graded beds) alternation with the light-dark alternating sediments of pelagic sedimentary origin. The visual criteria I used to distinguish turbidites from pelagic alternation are abrupt contacts (particularly between basal light beds and upper dark beds) and the presence of grading. In pelagic cycles the darker, more organic-matter- and clay-rich layers are friable and commonly laminated, whereas the lighter beds are commonly bioturbated.

The origin of the sediment cycles is generally ascribed to paleoceanographic shifts in productivity, in circula-

\footnotetext{
${ }^{1}$ van Hinte, J. E., Wise, S. W., Jr., et al., Init. Repts. DSDP, 93: Washington (U.S. Govt, Printing Office), 20546.
}

tion, or in bottom-water characteristics. The role of diagenesis in modifying or enchancing original differences has not been clearly identified. In particular, bulk carbonate isotope samples are interpreted without sufficient attention to mineralogic or geochemical associations or to microscopic textures which may indicate diagenetic modification.

In this paper I compare analyses of the light and dark extremes of a sedimentary cycle, beginning with qualitative geochemical composition. I then present results of stable isotope $\left(\delta^{13} \mathrm{C}\right.$ and $\left.\delta^{18} \mathrm{O}\right)$ analyses of six light-dark cycles and finally present textural evidence on an electronic microscopic scale to explain the immediate reasons for the isotopic trends observed.

\section{METHODS}

Six intervals of pelagic sediments containing light-dark cycles were selected for $\delta^{13} \mathrm{C}$ and $\delta^{18} \mathrm{O}$ analyses of $\mathrm{CaCO}_{3}$ from the ValanginianBarremian sediments of Hole 603B. Bulk samples were powdered and dried at room temperature. Isotopic analyses were presented in the usual per mil $\delta$-notations,

$$
\begin{aligned}
\delta^{13} \mathrm{C}^{\left({ }_{\infty}\right)} & =\left(\frac{{ }^{13} \mathrm{C} /{ }^{12} \mathrm{C} \text { sample }-{ }^{13} \mathrm{C} /{ }^{12} \mathrm{C} \text { reference }}{{ }^{13} \mathrm{C} /{ }^{12} \mathrm{C} \text { reference }}-1\right) \times 1000 \\
\delta^{18} \mathrm{O} & =\left(\frac{{ }^{18} \mathrm{O} /{ }^{16} \mathrm{O} \text { sample }-{ }^{18} \mathrm{O} /{ }^{16} \mathrm{O} \text { reference }}{{ }^{18} \mathrm{O} /{ }^{16} \mathrm{C} \text { reference }}-1\right) \times 1000
\end{aligned}
$$

and values are reported relative to the Peedee Belemnite (PDB) marine carbonate standard.

Representative samples of light and dark sediment extremes were selected for scanning electron microscopy (SEM; Amray 1500) and energy dispersive spectrometry (EDS; Tracor 550). Samples were mounted on SEM stubs, stored in a desiccator at room temperature and carbon-coated prior to examination under the SEM.

EDS results are qualitative. Elemental peak heights (in Fig. 2) vary with the relative amount of the element, and the vertical scale is automatically adjusted to accommodate the highest peak. Only major elements occur in sufficiently high concentrations to be detected. 


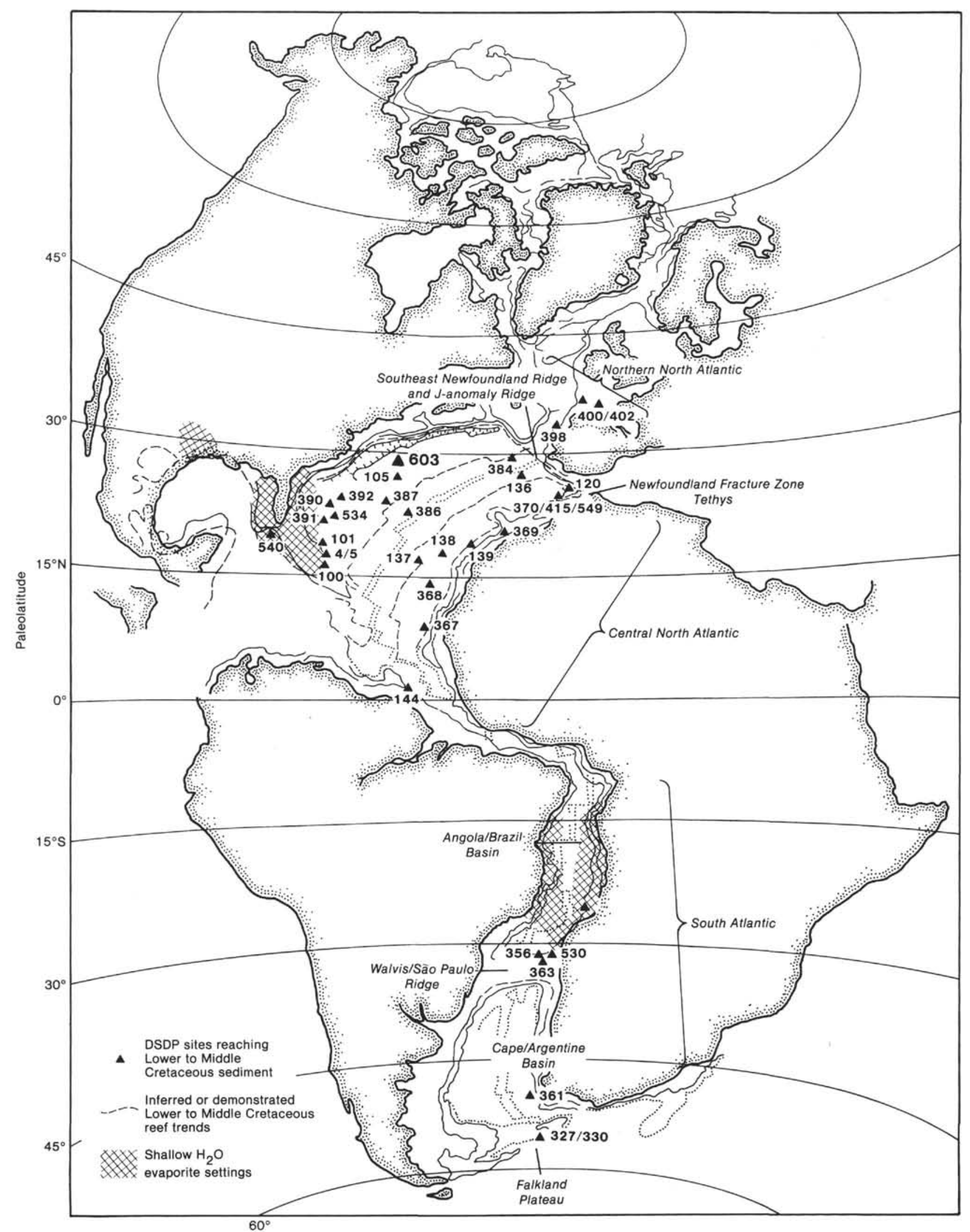

Figure 1. DSDP sites in the Atlantic that recovered Lower Cretaceous organic-matter-rich or rhythmically bedded sediment, plotted on reconstruction from $110 \mathrm{Ma}$. Reconstruction from Sclater et al. (1977); figure modified from Arthur (1979). 


\section{RESULTS}

\section{Qualitative Geochemical Analysis}

Figure 2 features EDS spectra of typical light and dark lithologies. In Figure 2A, the spectrum featured is that of a typical light limestone end member of a light-dark cyclic alternation; the elements detected are calcium, aluminum, and silicon. This interval of light limestone contains about $90 \% \mathrm{CaCO}_{3}$ and about $0.1 \%$ organic carbon (based on shipboard carbonate bomb and Rock-Eval analyses; see Site 603 chapter, this volume). The large amount of carbonate resides mainly in nannofossil tests in the sediment (Site 603 chapter, this volume) and is responsible for the dominance of Ca peaks $\left(\mathrm{k} \alpha_{1}\right.$ and $\left.\mathrm{k} \alpha_{2}\right)$ in the spectrum; the $\mathrm{Al}$ and $\mathrm{Si}$ demonstrate the presence of clay in sample.

Figures $2 \mathrm{~B}$ and $2 \mathrm{C}$ are spectra from the same piece of dark marl, $2 \mathrm{~mm}$ in diameter. In addition to the $\mathrm{Ca}, \mathrm{Al}$, and $\mathrm{Si}$ seen in the light limestone, the EDS detects the presence of iron and potassium in Figure 2B. Moving the electron beam slightly resulted in the spectrum seen in Figure 2C: $\mathrm{Fe}$ and $\mathrm{S}$ attain significant peak heights because pyrite is present. A typical dark marl is still carbonate-rich: shipboard carbonate bomb analyses indicate $75-80 \% \mathrm{CaCO}_{3}$ in dark marl and Rock-Eval analyses show typically about $0.5 \%$ organic carbon (Site 603 chapter, this volume).

The difference in organic carbon content between the light limestone and dark marl is thus not so great as the color contrast would suggest. Darkness in the marl is probably due in large part to the dispersed presence of pyrite and the higher concentration of clay.

\section{$\delta^{13} \mathbf{C}$ and $\delta^{18} \mathrm{O}$ Analyses}

Three or four samples from each of six light-dark pelagic sediment cycles were selected to represent the lithologies in a typical cycle and powered for bulk-sample stable isotope analysis of the carbonate fraction. Two adjacent cycles were sampled from Cores 603B-74 and -77 . Table 1 lists sample lithology and isotopic composition.

Figure 3 illustrates the range of values and depths of samples analyzed. The youngest cycle studied is from Core 603B-49 of late Barremian age; the oldest cycle is from Core 603B-82 of Berriasian age (see Site 603 chapter, this volume).

Consistently in all cycles, carbon is heavier by a 0.5 to $1.5 \%$ in the dark marl than in the light limestone; only one point departs from this generalization (Figure 4A). The same trend is observed in oxygen (Fig. 4B), which in the darker marl is consistently heavier by 0.2 to $7.5 \%$ than in the lighter limestone.

In addition to trends within cycles, Figure 3 shows depth-related shifts is isotopic composition. Oxygen in light limestone becomes isotopically lighter with greater burial depth, whereas oxygen in dark marl appears slightly heavier with depth, although the trend in the dark marl is less clear. Carbon is heavier with greater burial depth in both dark marl and light limestone.

\section{Discussion of $\delta^{13} \mathrm{C}$ and $\delta^{18} \mathrm{O}$ Values}

A lithology-correlatable shift in the carbon or oxygen isotopic composition of carbonate in the sediment reflects either the environmental shift associated with the different lithologies (thus recording primary sedimentary conditions) or the difference in the microenvironment in which the different lithologies underwent diagenesis. Microenvironmental differences might result from different pore water chemistry or reflect temperature differences as a function of the rate of diagenesis. Burial temperature would be greater in sediments of slower diagenetic rate (thus resulting in lighter oxygen but having little effect on carbon), but of minor significance in sediments that undergo little more than compaction in their postburial history (Bathurst, 1971).

A shift toward heavier inorganic carbon has been observed in the clayey, organic-matter-rich portion of rhythmically bedded carbonate sediments of other Early Cretaceous localities on land and from the seafloor (e.g., Scholle and Arthur, 1980; Weissert et al., 1979; Boer, 1982; Létolle et al., 1978). These workers attribute the positive shifts to periods of increased surface-water productivity or to increased preservation of organic material in sediments on the seafloor.

Photosynthesis results in the preferential removal of isotopically light carbon $\left({ }^{12} \mathrm{C}\right)$ from surface water. The ${ }^{12} \mathrm{C}$ is then transferred to the bottom water or sediments with organic matter. If the organic matter is preserved, the ${ }^{12} \mathrm{C}$ is removed from the carbon cycle. Thus increased photosynthesis (productivity) and increased preservation of organic matter deplete the oceanic reservior of ${ }^{12} \mathrm{C}$, enriching it in ${ }^{13} \mathrm{C}$.

The consistently heavier oxygen in the dark marly layers may be a function of primary circumstances (e.g., climatic cycles) or of diagenetic processes. A straightforward means of distinguishing between these is to look for evidence of different diagenetic history of the two end members of light/dark cyclic bedding: if preservation of the $\mathrm{CaCO}_{3}$ components is similar, the difference in oxygen isotope composition within a cycle is probably not a diagenetic product. Conversely, if there is evidence of different degrees of dissolution or overgrowth of $\mathrm{CaCO}_{3}$ between the light limestone and dark marl, the oxygen isotope difference within a cycle probably has a diagenetic origin. The slight decrease in ${ }^{18} \mathrm{O}$ with depth, such as that observed in the limestone of Figure 3 , is typical of carbonate burial diagenesis (Garrison, 1981).

The trend of heavier carbon with depth (or age) in Lower Cretaceous sediments contrasts with the ${ }^{13} \mathrm{C}$ record published by Scholle and Arthur (1980) for Lower Cretaceous sediments of Peregrina Canyon (Mexico), which shows a trend of lighter carbon with age. Two other Early Cretaceous isotope records from DSDP Holes 367 and 391C show a less pronounced trend of lighter carbon with age (Scholle and Arthur, 1980). If the trend of carbon with depth observed in Hole 603B is much different from the global curve, the difference may be 
A

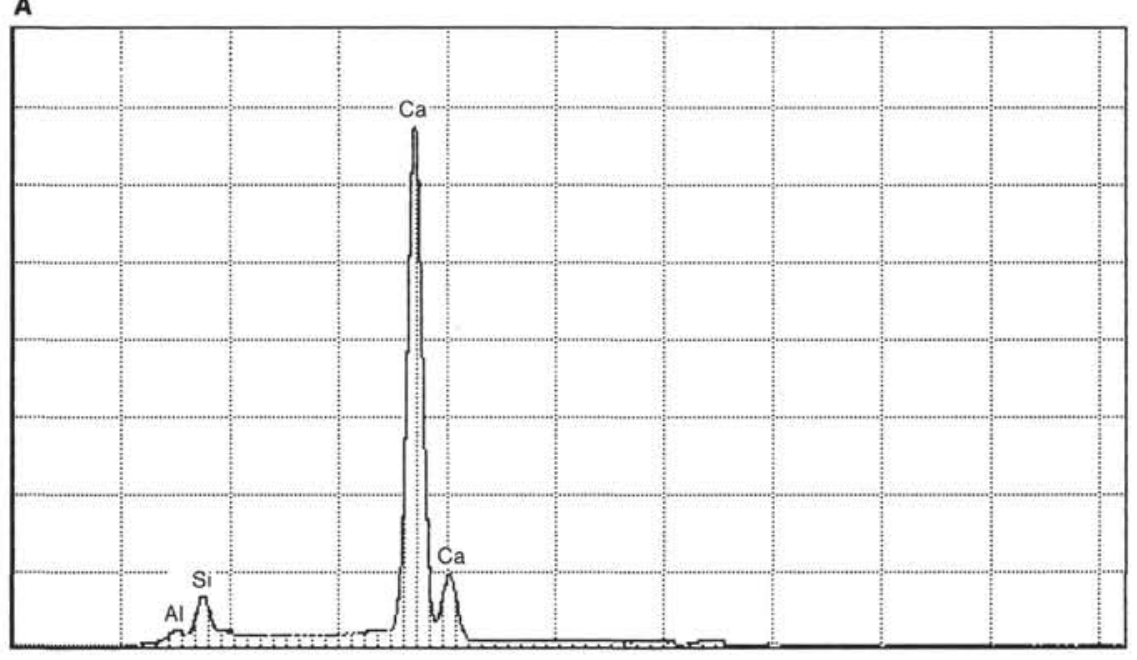

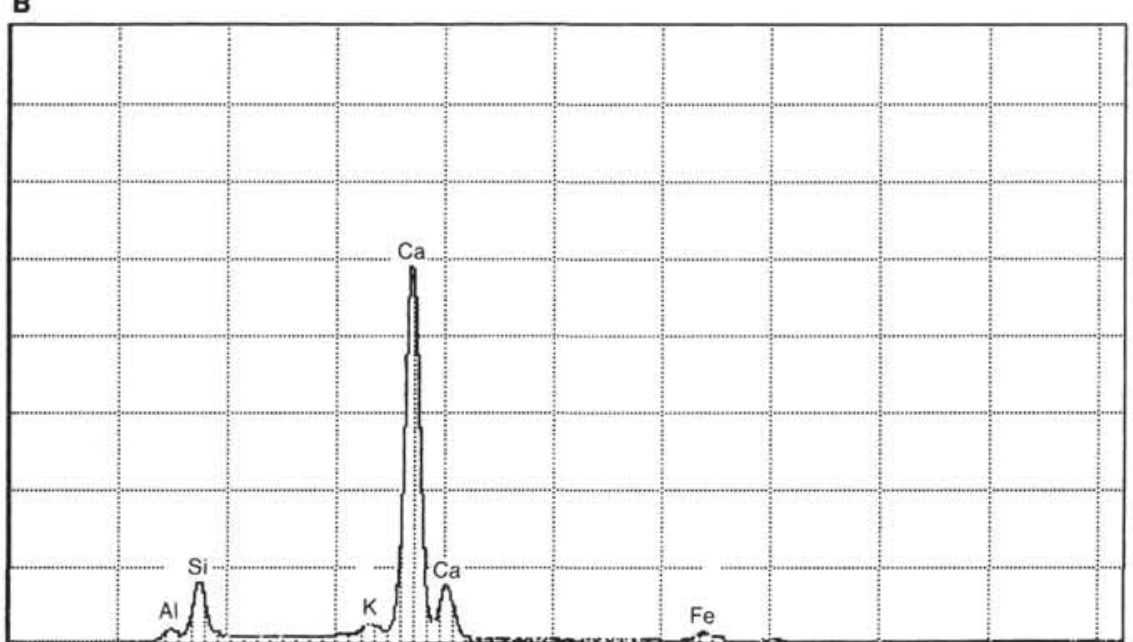

c

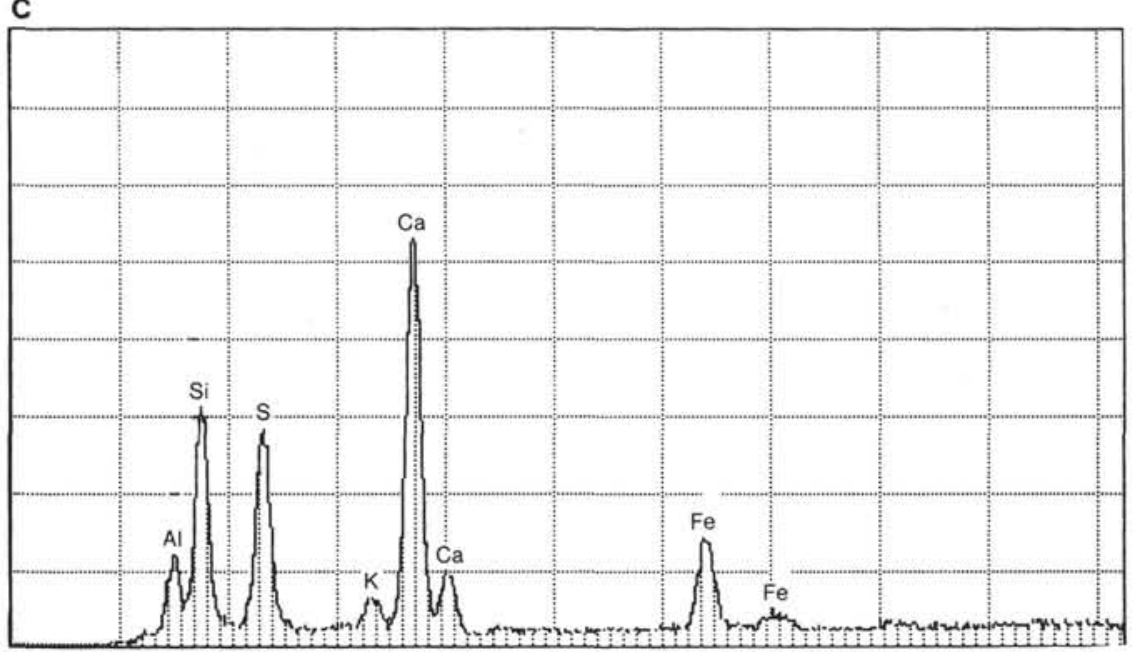

Figure 2. Energy-dispersive spectrometer displays for typical end-member lithologies of light-dark cyclic bedding. Vertical scale indicates number of counts of different elements over a 60 -s interval; the scale is automatically adjusted to accommodate the highest peak. Horizontal scale runs from 0 to $10 \mathrm{keV}$. A. Light, bioturbated limestone is composed predominantly of Ca (derived from calcium carbonate), $\mathrm{Al}$, and $\mathrm{Si}$ (from clays). Sample 603B-74-2, 95-96 cm. B. Darker, laminated marl is composed predominantly of Ca, $\mathrm{Si}$, and $\mathrm{Al}$ with minor $\mathrm{Fe}$ (probably from pyrite) and $\mathrm{K}$ (probably clays); observable peak is due to higher concentration of clays in this specimen. Sample $603 \mathrm{~B}-82-3,122-123 \mathrm{~cm}$. C. Same sample as in B. Shifting the beam slightly on the sample resulted in much higher Fe peaks and the appearance of an S peak, confirming the conjectured presence of FeS. Aluminosilicates (probably clays) occur in greater concentration in this area of the sample. 
Table 1. Carbon and oxygen isotope composition of carbonate sediments from the Lower Cretaceous of Hole 603B.

\begin{tabular}{|c|c|c|c|}
\hline $\begin{array}{l}\text { Core-Section } \\
\text { (interval in } \mathrm{cm} \text { ) }\end{array}$ & Lithology & ${ }_{8}^{18} \mathrm{O}\left(\%_{0} \mathrm{PDB}\right)$ & $\delta^{13} \mathrm{C}\left(\%_{0} \mathrm{PDB}\right)$ \\
\hline $49-4,19-20$ & Laminated light limestone & -2.88 & 0.23 \\
\hline $49-4,20-21$ & Laminated light limestone & -2.89 & 0.28 \\
\hline $49-4,75-76$ & Darker marl & -2.90 & 0.40 \\
\hline $51-2,58-59$ & Laminated light limestone & -2.63 & -1.57 \\
\hline $57-2,135-136$ & $\begin{array}{l}\text { Slightly bioturbated medium } \\
\text { marl }\end{array}$ & -3.83 & 0.24 \\
\hline $62-5,29-30$ & Slightly bioturbated marl & -4.27 & -0.04 \\
\hline $66-2,49-50$ & White bioturbated limestone & -4.29 & 0.93 \\
\hline $71-6,80-81$ & $\begin{array}{l}\text { Light laminated slightly } \\
\text { bioturbated limestone }\end{array}$ & -4.22 & 1.14 \\
\hline $74-2,95-96$ & White bioturbated limestone & -5.11 & 1.71 \\
\hline $74-2,118-119$ & Very dark marl & -2.44 & 1.45 \\
\hline $74-2,120-121$ & Dark marl & -1.66 & 2.43 \\
\hline $74-2,134-135$ & Dark laminated marl & -2.65 & 1.99 \\
\hline $74-2,150-151$ & White limestone & -4.42 & 1.58 \\
\hline $77-1,79-80$ & White limestone & -3.69 & 1.03 \\
\hline $77-1,95-96$ & Laminated marl & -2.84 & 1.34 \\
\hline $77-1,105-106$ & White limestone & -4.06 & 1.07 \\
\hline $77-1,116-117$ & Med. dark laminated marl & -2.08 & 1.67 \\
\hline $77-1,129-130$ & White limestone & -3.93 & 1.15 \\
\hline $82-3,86-87$ & Dark laminated marl & -2.17 & 1.60 \\
\hline $82-3,100-101$ & White limestone & -4.28 & 1.19 \\
\hline $82-3,122-123$ & Dark bioturbated marl & -2.98 & 1.72 \\
\hline
\end{tabular}

${ }^{a}$ Two cycles sampled over this interval.

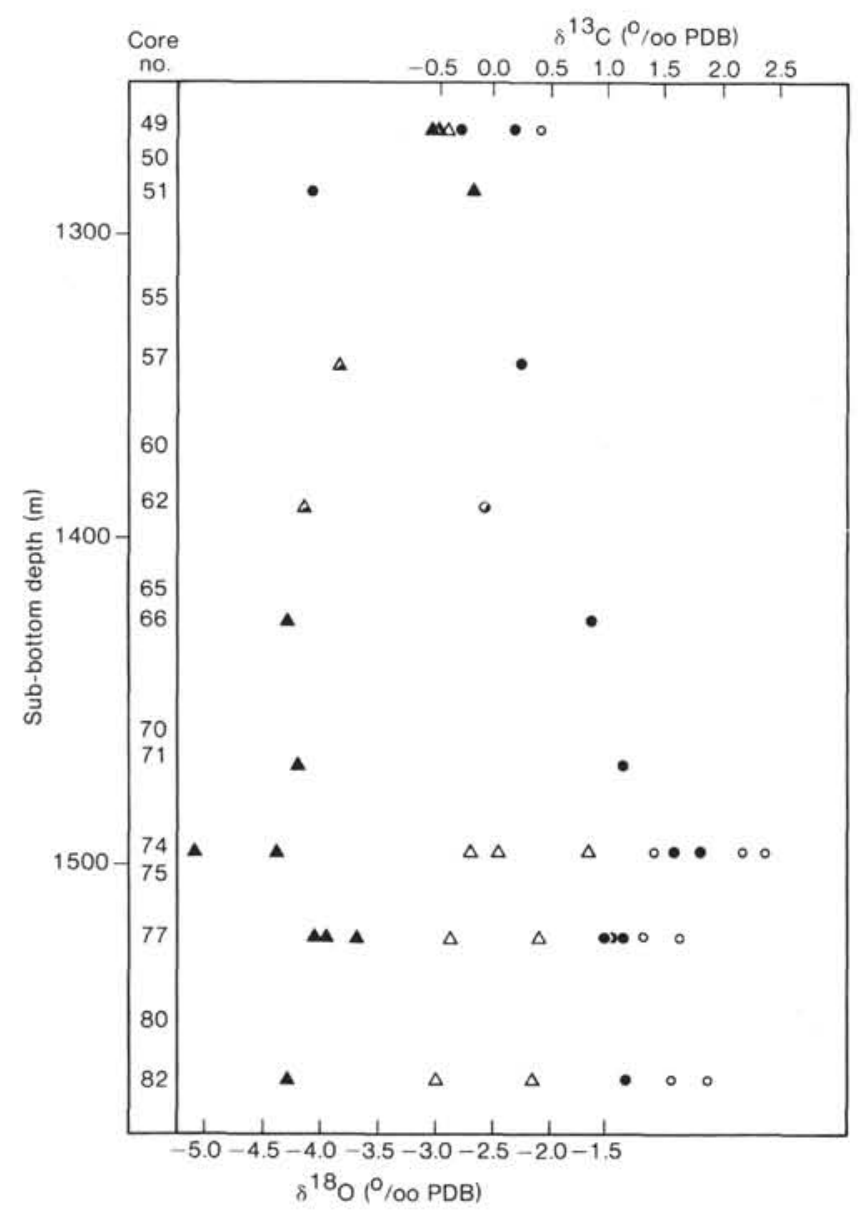

Figure 3. $\delta^{13} \mathrm{C}$ and $\delta^{18} \mathrm{O}$ values for samples listed in Table 1 plotted against sub-bottom depth in Hole 603B. Circles are $\delta^{13} \mathrm{C}$ values; solid circles are light limestone or marl, open circles are dark marl. Triangles are $\delta^{18} \mathrm{O}$ values; solid triangles are light limestone or marl and open triangles are dark marl. Half-filled symbols indicate a sample of intermediate lithology. due to diagenetic process or to local paleoceanographic conditions. Examination of the lithologies under high magnification on the SEM can be used to identify the influence of diagenesis on geochemical and isotopic composition.

\section{Scanning Electron Microscope Observations}

Typical dark marl and light limestone end members of the light-dark cycles were mounted for high-magnification examination on the SEM, they display a pronounced textural difference (Fig. 5 and 6). The dark marl commonly has a rough surface, reflecting in part small-scale overgrowth (Fig. 5A). Regions of higher carbonate content contain carbonate grains and nannofossils with edges apparently rounded by dissolution (Fig. 5B). The layered appearance in photographs probably reflects the higher clay content of the marl.

In contrast, the light limestone lacks the appearance of layering. Instead of the rounded edges displayed by constituents of the dark marl, the original, sharp, angular edges of nannofossils are apparently commonly preserved. Calcite crystal overgrowth is widespread and develops to a larger crystal size than in the marl (Fig. 6).

Nannofossils appear to be generally better preserved in the light limestone, although crystal overgrowth is widespread. Although some overgrowths can be seen in the dark marl, the removal of carbonate through dissolution seems to dominate.

\section{SUMMARY AND CONCLUSIONS}

We have seen that the visible lithologic difference between the light and dark end members of a Lower Cretaceous pelagic carbonate cycle correspond to geochemical and mineralogic differences: compared with the light limestone, the dark marl contains less calcium carbonate and more clay, dispersed pyrite that is locally abundant in a sample, and more organic carbon. The dark color of the laminated marl can be attributed to its higher clay, organic-matter, and pyrite content; its friable texture is due both to lack of bioturbation and to higher clay content.

The two lithologies also differ isotopically; carbonate from the dark marl contains heavier carbon and oxygen. Following the arguments of Arthur (1979), Scholle and Arthur (1980), Boer (1982), Weissert et al. (1979, 1985 ) and others, I attribute the shift toward heavier carbon to an increase either in the productivity of surface waters or in the preservation of organic material reaching the seafloor, although the effect of diagenesis may be reflected in large-scale $\delta^{13} \mathrm{C}$ trends with burial depth. Most of the workers mentioned above favor greater preservation, citing lower oxygen content in the oceans as the reason for higher preservation of organic matter (Jenkins, 1980). Either mechanism will strip the waters of ${ }^{12} \mathrm{C}$ by removing it from organic carbon, eventually enriching the oceans in ${ }^{13} \mathrm{C}$.

SEM textural studies indicate that there is a preservational difference between light limestone and dark marl end members of a cycle. The rough surface of the dark marl exhibits modest layering under high magnification. 

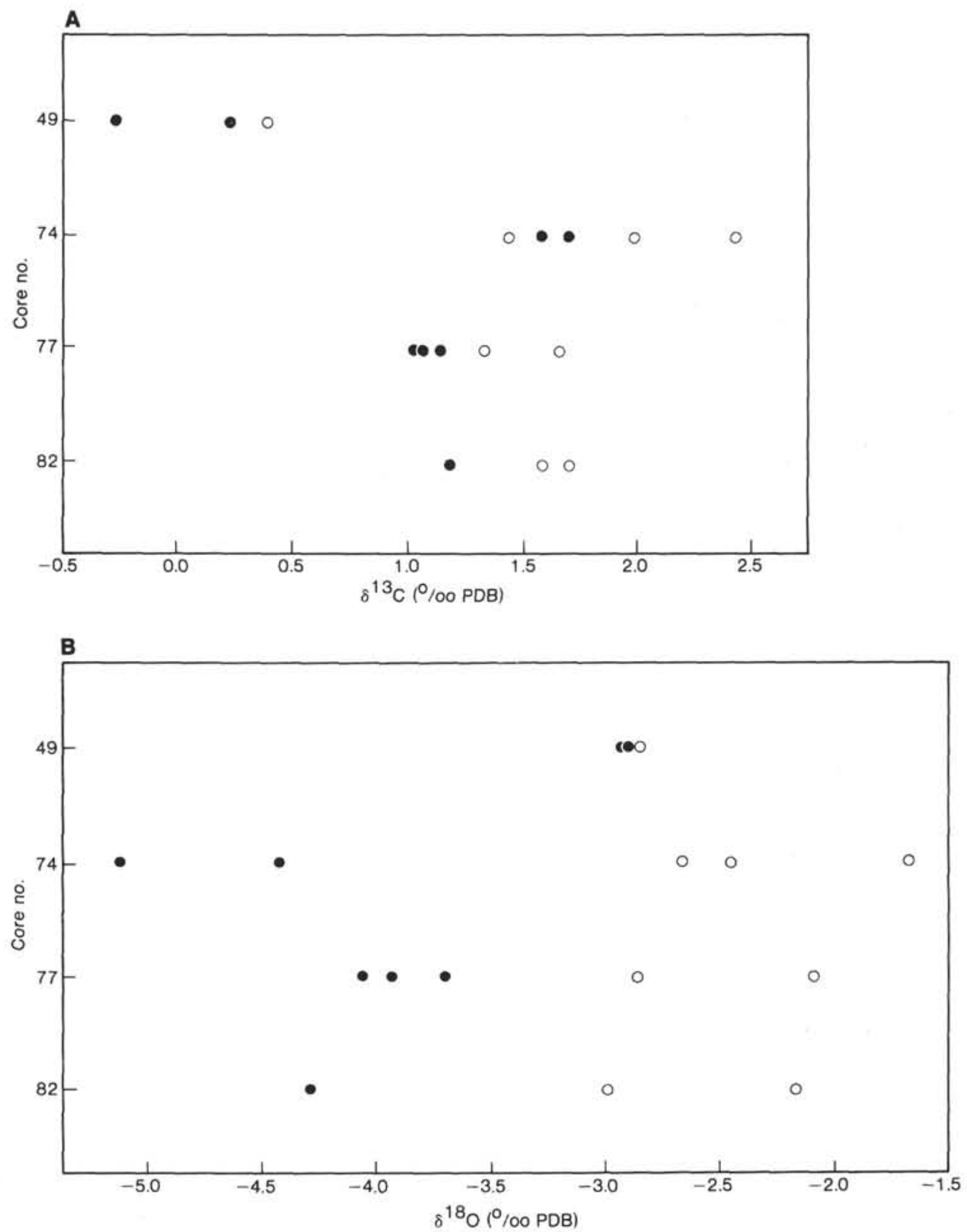

Figure 4. A. $\delta^{13} \mathrm{C}$ values for six light-dark cycles plotted against core number. In Cores 603B-74 and -77 two consecutive cycles were sampled. With the exception of one point in Core 603B-74, dark marls contain consistently heavier carbon than light limestone or marl within a cycle. B. $\delta^{18} \mathrm{O}$ values from the six light-dark cycles, as in A. Without exception, the dark marl in the cycle contains heavier oxygen than the light limestone. Open and filled circles as in Figure 3.

Regions locally enriched in calcium carbonate show particle edges and coccolith plates that are rounded by dissolution. The light limestone appears to have a higher proportion of well-preserved coccoliths with angular plate edges but also exhibits larger grains and more overgrowth, which is probably the source of its lighter oxygen. Precipitation of calcite under elevated burial temperatures during diagenesis would result in the light $\delta^{18} \mathrm{O}$ in these samples.

\section{ACKNOWLEDGMENTS}

This study was partially funded by the National Science Foundation (OCE 82-07711). The author benefited from discussions with Dr.
E. L. Winterer and Dr. J. G. Ogg and thanks Dr. J. McKenzie for the improvements in this paper resulting from her thorough review. M. Beach drafted the figures.

\section{REFERENCES}

Arthur, M. A., 1979. North Atlantic Cretaceous black shales: The record at Site 398 and a brief comparison with other occurrences. In Sibuet, J.-C., Ryan, W. B. F., et al., Init. Repts. DSDP, 47, Pt. 2: Washington (U.S. Govt. Printing Office), 719-752.

Arthur, M. A., and Fischer, A. G., 1977. Upper Cretaceous-Paleocene magnetic stratigraphy at Gubbio, Italy: I. lithostratigraphy and sedimentology. Geol. Soc. Am. Bull., 88:367-387.

Arthur, M. A., and Natland, J. H., 1979. Carbonaceous sediments in the North and South Atlantic: the role of salinity in stable stratification of Early Cretaceous basins. In Talwani, M., Hay, W., and 
Ryan, W. B. F. (Eds.), Deep Drilling Results in the Atlantic Ocean: Continental Margins and Paleoenvironment: Washington (American Geophysical Union), pp. 375-401.

Bathurst, R. G. C., 1971. Carbonate Sediments and Their Diagenesis: Amsterdam (Elsevier).

Boer, P. L., de 1982. Cyclicity and the storage of organic matter in Middle Cretaceous pelagic sediments. In Einsele G., and Seilacher, A. (Eds.), Cyclic and Event Stratification: New York (Springer Verlag), pp. 456-475.

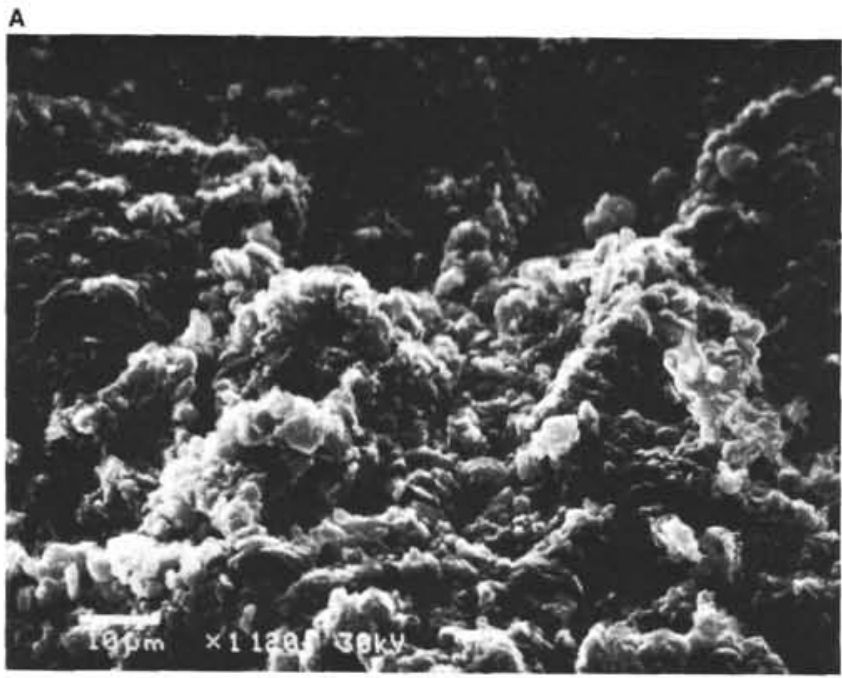

B

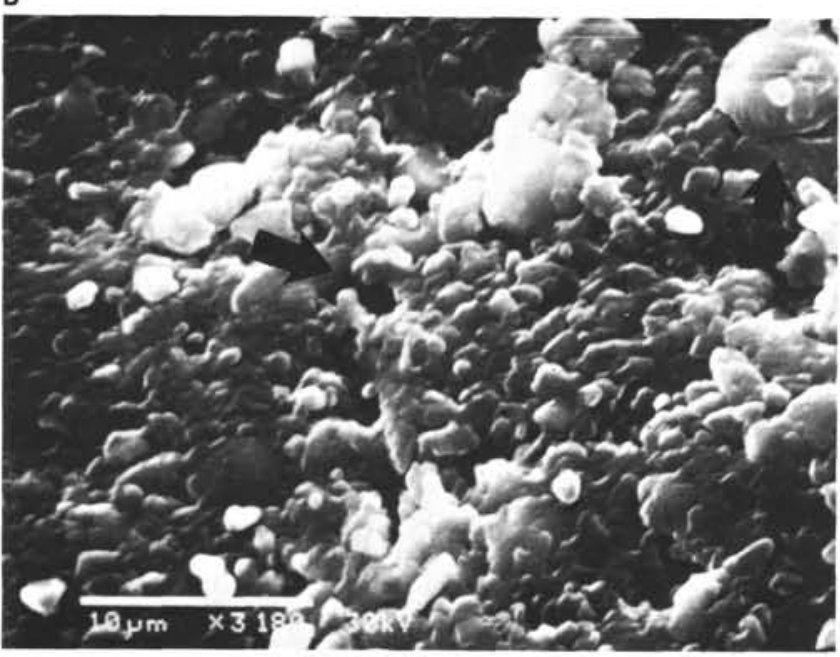

Figure 5. A. SEM photograph of a dark marl under high magnification. Note generally rough surfaces and layered appearance. Scale bar is $10 \mu \mathrm{m}$. Sample 603B-82-3, 122-123 cm. B. SEM photograph of a different region on the same sample. Note rounded edges of carbonate grains and stacked appearance. Arrows point to the dissolution-rounded edges of the incomplete circlet of a coccolith plate in the photo center and to small-scale crystal overgrowth on a coccolith in the upper right corner of photograph. Scale bar is $10 \mu \mathrm{m}$.
Dean, W. E., Gardner, J. V., Jansa, L. F., Cepek, P., and Siebold, E., 1978. Cyclic sedimentation along the continental margin of northwest Africa. In Lancelot, Y., Siebold, E., et al., Init. Repts. DSDP, 41: Washington (U.S. Govt. Printing Office), 965-989.

Garrison, R. E., 1981. Diagenesis of ocean carbonate sediments: a review of the D.S.D.P. perspective. In Warme, J. E., Douglas, R. G., and Winterer, E. L. (Eds.), The Deep Sea Drilling Project: A Decade of Progress. Soc. Econ. Paleontol. Mineral. Spec. Publ., 32: 181-207.

Jenkins, H. C., 1980. Cretaceous anoxic events: from continental to oceans. J. Geol. Soc., 137:171-188.

Létolle, R., Renard, M., Bourbon, M., and Filly, A., 1978. ${ }^{18} \mathrm{O}$ and ${ }^{13} \mathrm{C}$ isotopes in Leg 44 carbonates: a comparison with the Alpine series. In Benson, W. E., Sheridan, R. E., et al., Init. Repts. DSDP, 44: Washington (U.S. Govt. Printing Office), 567-574.

Robertson, A. H. F., and Bliefnick, D. M., 1983. Sedimentology and origin of Lower Cretaceous pelagic carbonates and redeposited clastics, Blake-Bahama Formation. Deep Sea Drilling Project Site 534, Western Equatorial Atlantic. In Sheridan, R. E., Gradstein, F. M., et al., Init. Repts. DSDP, 76: Washington (U.S. Govt. Printing Office), 795-828.

Scholle, P. A., and Arthur, M. A., 1980. Carbon isotope fluctuations in Cretaceous pelagic limestones: potential stratigraphic and petroleum exploration tool. Am. Assoc. Pet. Geol. Bull., 64:67-87.

Sclater, J. G., Hellinger, S., and Tapscott, C., 1977. The paleobathymetry of the Atlantic Ocean from the Jurassic to the present. J. Geol., $85: 509-522$.

Weissert, H., McKenzie, J., and Channell, J. E. T., 1985. Natural variations in the carbon cycle during the Early Cretaceous. In Sundquist, E. T., and Broecker, W. S. (Eds.), The Carbon Cycle and Atmosphere $\mathrm{CO}_{2}$ : Natural Variations Archean to Present. Geophys. Mon., 32:531-545.

Weissert, H., McKenzie, J., and Hochuli, P., 1979. Cyclic anoxic events in the Early Cretaceous Tethys Ocean. Geology, 7:147-151.

Date of Initial Receipt: 13 March 1985

Date of Acceptance: 3 October 1985

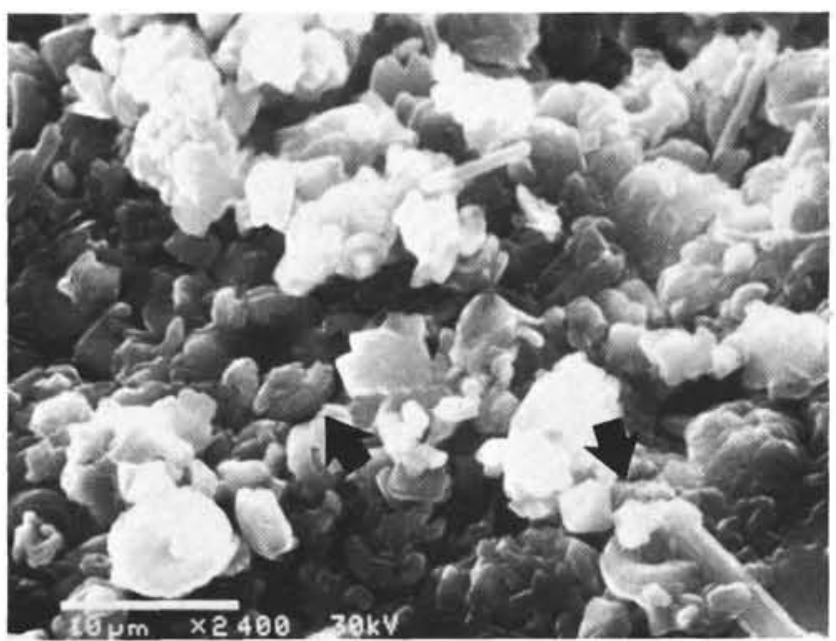

Figure 6. SEM photo of a light limestone. Calcite grains are large, with sharp, angular edges. Coccoliths are well preserved with original edges intact (arrows). Abundant calcite overgrowth on other grains may account for the lighter oxygen associated with this lithology. Scale bar is $10 \mu \mathrm{m}$. Sample 603B-74-2, 94-95 cm. 